Historia Slavorum Occidentis

2021, nr 1 (28)

ISSN 2084-1213

DOI: $10.15804 /$ hso210102

Zigigniew Robak (Nitra)

ORCID: 0000-0002-4819-468X

\title{
Wczesnośredniowieczne grodzisko Bojná-Valy na Słowacji. Nowe interpretacje*
}

Słowa kluczowe: wczesne średniowiecze, grodziska, Słowacja

Keywords: Early Middle Ages, hillforts, Slovakia

Abstract: The Early Medieval hillfort Bojná-Valy in Slovakia is among the best known structures of this type in Europe. Until recently, it was attributed central functions but a new hypothesis suggests that it served as a kind of barracks.

\section{Wstęp}

Grodzisko Bojná-Valy egzystuje w literaturze naukowej, popularno-naukowej i powszechnej świadomości laików interesujących się historią Wielkich Moraw i Słowacji jako siedziba słowiańskich elit z czasów księcia Pribiny, a więc z początków IX w. Tak w ogromnym uproszczeniu brzmiała też hipoteza postawiona na początku badań nad tym obiektem ${ }^{1}$. Dziś, po 13 latach prac wykopaliskowych i badawczych wiemy, że datowanie umocnień grodziska Bojná-Valy należy umieszczać bliżej prze-

\footnotetext{
* Artykuł powstał w ramach projektów badawczych (1:1): APVV-19-0563 „Mocenské centra a ich zázemie v 8.-11. storočí” a VEGA 2/0001/18 „Slovensko a stredné Podunajsko: vývoj od včasnej doby dejinnej po začiatok stredoveku”.

1 Bojná. Hospodárske a politické centrum Nitrianskeho kniežatstva, red. K. Pieta, A. Ruttkay, M. Ruttkay, Nitra 2006.
} 
łomu IX i X w., a więc w czasach rządów Świętopełka i jego synów, i z dużą dozą niepewności tylko wskazywać na możliwość wcześniejszego zasiedlenia tego terenu, jednakże nie wcześniej niż około połowy IX w. ${ }^{2}$ Dopiero po latach prac badawczych i wstępnym opracowaniu ich wyników zaczyna klarować się obraz kulturowy, który może posłużyć do postawienia innej hipotezy badawczej, diametralnie jednak różnej od pierwotnej, która będzie kierować pracami badawczymi przez następne lata. Czym w takim razie mógł być ten obiekt? Jaką funkcję pełniło to potężne grodzisko i komu służyło?

\section{Charakterystyka i położenie grodziska}

Grodzisko Bojná-Valy jest zlokalizowane w południowej części pogórza Považský Inovec, rozdzielającego szerokie doliny rzeczne środkowego Wagu i środkowej Nitry. Jest to typowe grodzisko wyżynne. Umocnienia obejmują szczyt oraz wąskie plateau jednego ze wzgórz centralnego masywu. $Z$ trzech stron wzgórze jest ograniczone płynącymi wąwozami potokami, z czwartej (zachodniej) odcięte wyraźnym obniżeniem, za którym teren ponownie się wznosi, już dość znacznie. Wysokość wzgórza sięga 430 m n.p.m. (przeciętnie 405-410 m n.p.m.), a relatywna wysokość (mierzona od poziomu dolin opływających go potoków) to około $150 \mathrm{~m}$.

Obiekt ma kształt zbliżony do prostokąta o długości około $600 \mathrm{~m}$ i szerokości około $200 \mathrm{~m}$ (ryc. 1). Zajmuje powierzchnię 10 ha, nie licząc powierzchni zajmowanej przez wał o długości 1340 m, którym jest otoczony. Wejście do areału umożliwiały dwie bramy ulokowane we wschodniej i zachodniej ścianie umocnień na osi grzbietu wzniesienia. Najdogodniejszy dostęp do grodziska prowadzi od wschodniej strony, gdzie łagodnie wznoszący się teren tworzy naturalne warunki komunikacji. Próba dostępu do grodziska od strony zachodniej wymaga już jego wcześniejszego okrążenia albo przeprawy przez wzgórza i podejścia stokiem opadającym od zachodu. W najwęższym i jednocześnie najniższym miejscu tego spadku wybudowano dodatkowy wał o długości 193 m przecinający stok w poprzek, tworząc tym samym podgrodzie o powierzchni 1,5 ha. Obiekt miał dodatkowo dwa wały przedłużające wschodnią ścianę umocnień i biegnące w poprzek stromych zboczy aż do dna wąwozów, co zapewne zapobiegało okrążaniu grodu bezpośrednio pod umocnieniami.

2 K. Pieta, Z. Robak, The Early Medieval Hillfort Bojná-Valy, Slovakia, and Its Defence System, Acta Archaeologica Carpathica 52 (2017), s. 329-351; Bojná 2. Nové výsledky výskumov včasnostredovekých hradísk, red. K. Pieta, Z. Robak, 2. wyd., Nitra 2017. 


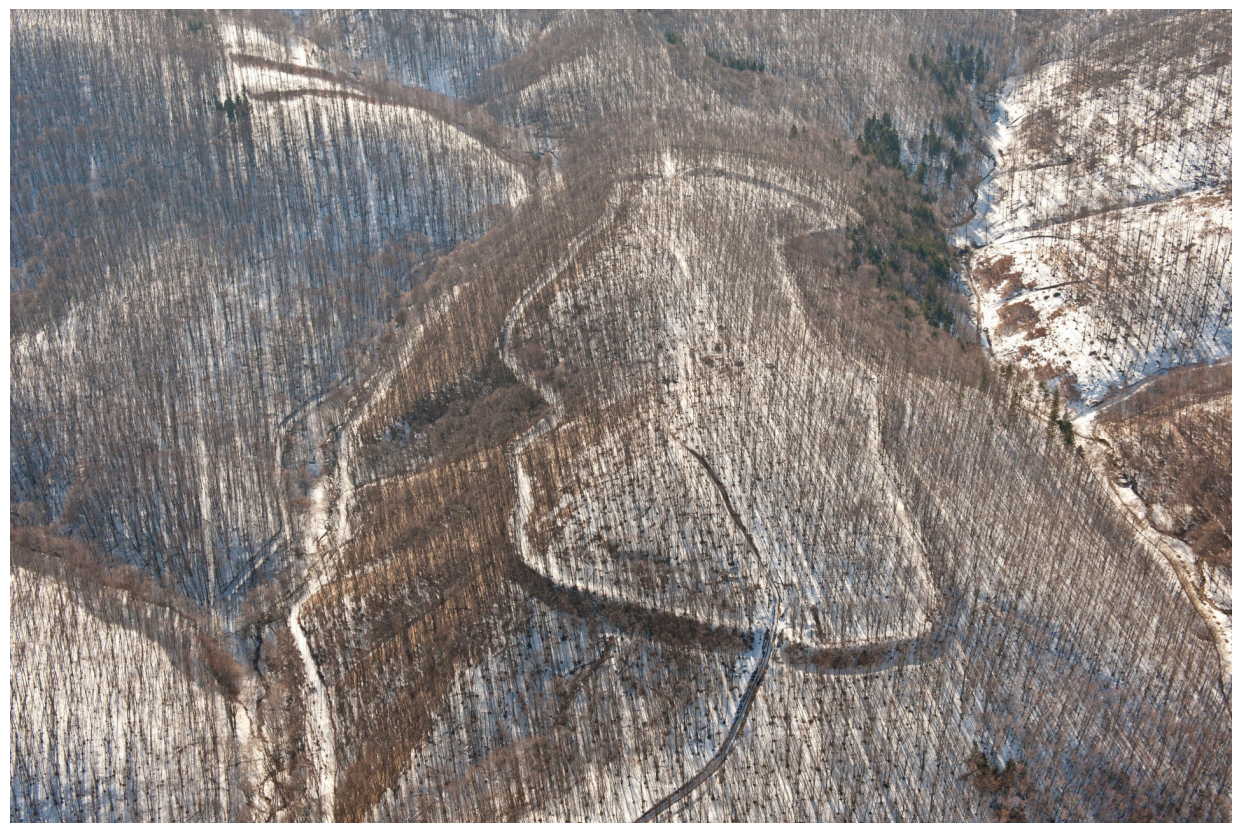

Ryc. 1. Grodzisko Bojná-Valy z lotu ptaka (foto: M. Ruttkay, AÚ SAV Nitra)

Już samo umiejscowienie kreuje grodzisko Bojná-Valy na obiekt typowo obronny, z funkcją kontroli szlaku komunikacyjnego. Położone jest bowiem z dala od gęsto zasiedlonych dolin rzecznych Nitry ( $5 \mathrm{~km}$ od krawędzi doliny) i Wagu (10 km od krawędzi doliny) w głębi masywu wzniesień. Wysokość wzniesienia przewyższa nieznacznie sąsiednie wzgórza leżące po wschodniej stronie, co czyniło to miejsce dogodnym punktem obserwacyjnym.

Położenie grodziska pozwalało (i w rzeczywistości nadal pozwala) kontrolować szlak komunikacyjny łączący w przeszłości (a funkcjonujący jeszcze w XIX w.) środkowe Ponitrze ze środkowym Poważem, a wiodący na Morawy. Szlak ten biegł wzdłuż rzeczki Bojnianka w kierunku wejścia do Hradnej doliny i dalej łagodnymi wzgórzami Žihl'avníka bądź doliną Hradnego potoku, w kierunku przełęczy Kamennych vrat, skąd wzgórza opadają już w stronę zachodnią i wypływają potoki stanowiące dorzecze $\mathrm{Wagu}^{3}$. We wczesnym średniowieczu szlak ten stanowil fragment najkrótszej i względnie wygodnej drogi, zarówno lądowej, jak i wodnej, łączącej

3 K. Pieta, A. Ruttkay, Bojná - mocenské a christianizačné centrum Nitrianskeho kniežatstva. Predbežná správa, [w: Bojná. Hospodárske a politické, s. 21-70, tu s. 23-25. 
Nitrę z aglomeracją Starégo Města na Morawach ${ }^{4}$. Relikty drogi, choć pochodzące zapewne z późniejszego niż IX-X w. okresu, wyznaczają też tradycyjne nazwy wejść do wąwozu Hradnej doliny - Vartovka (wartownia) i Kamenné vráta (kamienne wrota), co sugeruje istnienie jakichś punktów kontrolnych w tych miejscach.

Choć położenie grodziska umożliwiało bezpośrednią kontrolę szlaku komunikacyjnego tylko na jego głównej linii, to grodzisko Valy nie stanowiło w okresie wielkomorawskim na obszarze południowego Považskiego Inovca jedynej twierdzy, a było otoczone siecią mniejszych umocnień zlokalizowanych w niewielkiej odległości od siebie. W większości wypadków były to relatywnie niewielkie grodziska powstałe w pradziejach, których wykorzystywanie w okresie wielkomorawskim potwierdziły znaleziska pochodzące z badań terenowych, głównie ostrogi bądź części ich zapięćs. Grodziska te tworzyły sieć punktów kontrolnych w rejonie wejść do sąsiednich dolin oraz na grzbietach wzniesień. Do tej pory zidentyfikowano sześć takich obiektów. Umocnienia te tworzą linię na skraju ponitrzańskiej ekumeny, a grodzisko Valy stanowi jej zasadniczy punkt. Podobną, choć gorzej rozpoznaną, sieć można wskazać na skraju poważskiej ekumeny, na zachodnich krawędziach Považskiego Inovca, u wylotów wąwozów strumieni uchodzących do Wagu (grodziska Ducové, Hubina-Hradište, Hrádok).

\section{Zaplecze osadnicze i cmentarzyska}

Grodzisko Valy (podobnie zresztą jak cały kompleks umocnień) jest zlokalizowane na skraju wczesnośredniowiecznego regionu osadniczego, jaki stanowiła dolina środkowej Nitry, na samej granicy z innym dużym regionem, czyli doliną środkowego Wagu ${ }^{6}$. Osadnictwo w dolinie Nitry koncentrowało się wzdłuż samej rzeki i jej prawego dopływu Radošinki. Mniejsze skupiska i pojedyncze ślady osadnicze rejestrowane są także w rejonie rzeczki Chotina i potoków do niej spływających.

4 D. Cendelín, P. Bolina, Význam reliktu dopravního pohybu při interpretacji velkomoravského hradiště u Bojné (okres Topol'čany), Archaeologia historica 40 (2015), s. 247-265.

5 K. Pieta, Hradiská Bojná II a Bojná III, [w:] Bojná. Hospodárske a politické, s. 173-190; tenże, Včasnostredoveké mocenské centrum Bojná - výskumy v rokoch 2007-2013, [w:] Bojná 2, s. 11-51; tenże, Laténske a včasnostredoveké hradisko vo Vozokanoch, okres Topolčany, [w:] tamże, s. 347-358; Z. Robak, K otázke počiatkov včasnostredovekého osídlenia Bojnej, [w:] tamże, s. 53-64.

6 M. Ruttkay, Vývoj osídlenia na strednom Dunaji v 6.-12 stor., [w:] Slovensko vo včasnom stredoveku, red. A.T. Ruttkay, M. Ruttkay, P. Šalkovský, Nitra 2002, s. 41-56. 
Grodzisko Valy nie ma zlokalizowanego bezpośredniego zaplecza osadniczego, to znaczy osady lub osad umiejscowionych w jego pobliżu. Należy oczywiście z góry zaznaczyć, że rozpoznanie powierzchniowe obszarów wyżynnych i górskich Słowacji jest dość słabe ze względu na bardzo duże zalesienie krainy. W warunkach takich wykrycie pozostałości osad otwartych za pomocą klasycznych badań powierzchniowych jest właściwie niemożliwe, jednakże okolice Bojnej od kilkunastu lat są przedmiotem zwiększonego zainteresowania archeologów, a badania powierzchniowe są prowadzone także z użyciem sprzętu elektronicznego i za pomocą rozpoznania nieinwazyjnego. Na żadnym z sąsiednich wzgórz nie odkryto do tej pory śladów osady otwartej, natomiast ślady osadnictwa wczesnośredniowiecznego na wzgórzu Valy ograniczają się tylko do grodziska i terenu bezpośrednio doń przylegającego w promieniu 100-200 m. Pomimo licznych znalezisk przedmiotów metalowych, w tym jednego skarbu grzywien siekieropodobnych i narzędzi rolniczych oraz nielicznych fragmentów wczesnośredniowiecznej ceramiki, w kilku wykopach sondażowych założonych w 2016 i 2019 r. na wschodnim i zachodnim przedpolu grodziska nie zarejestrowano nawet warstwy kulturowej. Badania geofizyczne, które objęły całe wypłaszczenie zachodniego przedpola grodziska oraz wybrane miejsca wschodniego przedpola, nie dały wyników wskazujących na możliwość istnienia tam obiektów archeologicznych. Pozostałe pobliskie wzgórza, ze względu na stopień nachylenia zboczy oraz wysokość partii szczytowych, niespecjalnie nadawałyby się pod osadnictwo, a już w szczególności trwałe osady o charakterze rolniczym. Najbliższe ślady osadnictwa otwartego, zlokalizowane w wyniku badań powierzchniowych prowadzonych w okolicy, zostały zarejestrowane w Vozokanach i Závadzie, w odległości około $5 \mathrm{~km}$ w linii prostej od grodziska Valy (ryc. 2).

Podobnie jak nie udało się w pobliżu grodziska odnaleźć śladów trwałego osadnictwa otwartego, tak brak jest na terenie grodu lub w jego pobliżu cmentarzyska, które mogłoby przynależeć do grodu Valy. Nie udało się go także odnaleźć w nieco dalszej okolicy. Najbliższe cmentarzysko datowane na okres wielkomorawski jest zlokalizowane w pobliżu wspomnianej osady w Závadzie ${ }^{7}$. Tworzy je 36 grobów, wśród których znajdowały się trzy groby z ostrogami, w tym jeden grób z mieczem.

7 D. Bialeková, Slovanské pohrebisko v Závade, Slovenská archeológia 30 (1982), s. 103-160; Z. Robak, The Sword and Sword-belt in Carolingian Times: The Warrior Burial 23 from Závada Reconsidered, Študijné Zvesti Archeologického Ústavu SAV 64 (2018), s. 149-177. 


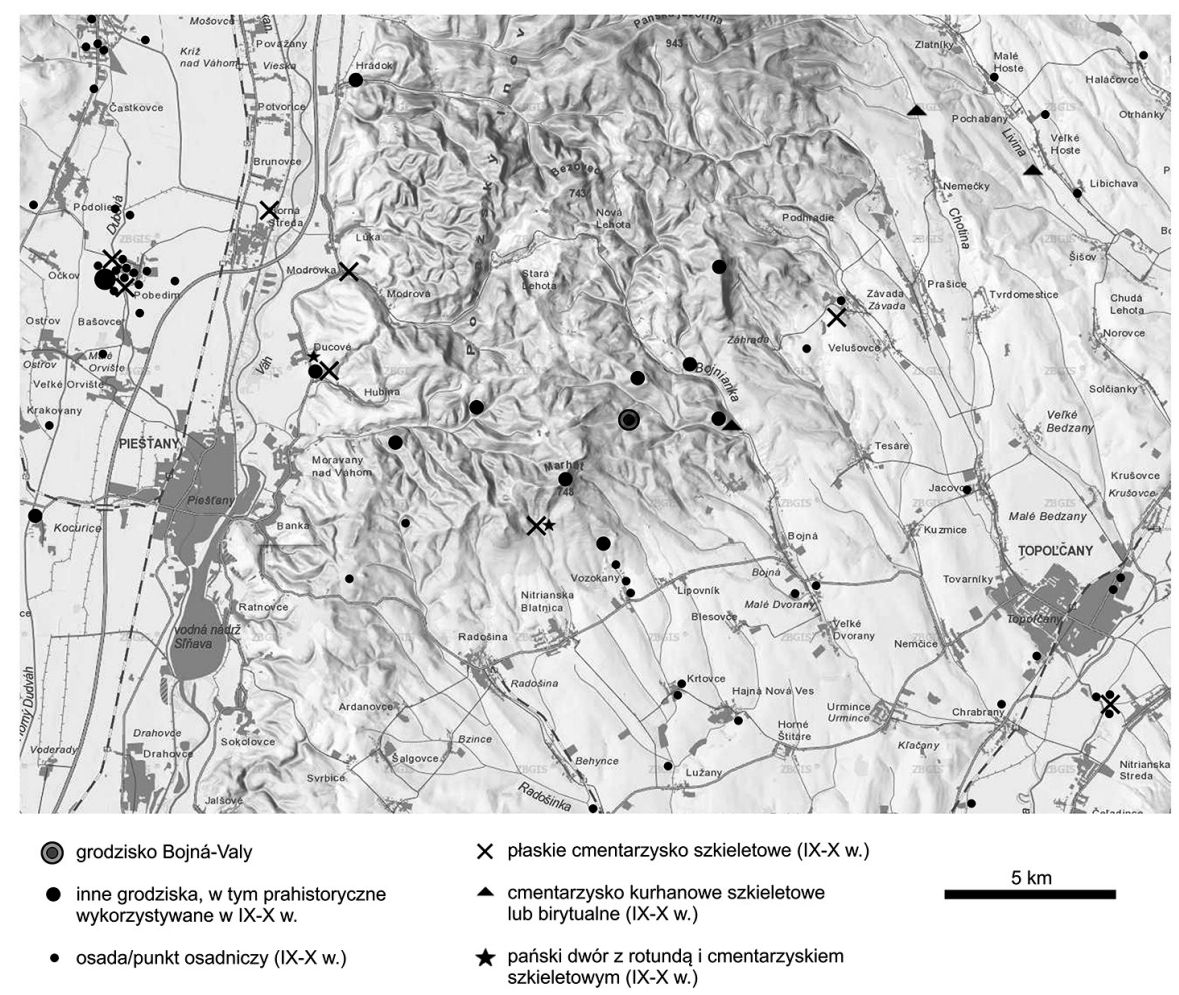

Ryc. 2. Wczesnośredniowieczne (IX-X w.) osadnictwo w rejonie południowej części Považskiego Inovca (autor: Z. Robak)

Osobną kwestią pozostaje interpretacja ekskluzywnego cmentarzyska kurhanowego na Žihl'avníku. Znajduje się ono w obrębie wałów grodziska, tuż przy jego południowym krańcu, skąd rozciąga się widok na całą dolinę Bojnianki oraz właściwie całą dolinę środkowej Nitry od Zoboru po Vtačnik. Cmentarzysko to tworzą dwa kurhany - wielki i mały - które powstały tam w schyłkowej fazie użytkowania grodziska lub po jego opuszczeniu. Oba obiekty datowane są na drugą połowę IX w. ${ }^{8}$, z tym że pochówek szkieletowy odnaleziono tylko pod mniejszym kurhanem. Wielki kurhan nie zawierał szczątków ludzkich, a jedynie resztki spalonych drewnianych elementów i dużą ilość kości zwierzęcych. Poza tymi kurhanami w okolicach Bojnej nie natrafiono na żadne inne pochówki wczesnośredniowieczne?

8 Z. Robak, K otázke počiatkov, s. 62.

9 D. Bialeková, Slovania po príchode a v období Vel'kej Moravy, [w:] Okres Topoličany. Hi- 


\section{Relacja z innymi obiektami obronnymi}

Położenie grodów na skrajach skupisk osadniczych jest zjawiskiem typowym dla wczesnośredniowiecznego osadnictwa w Karpatach Zachodnich, a jego celem była ochrona punktów dostępowych do zasiedlonych obszarów ${ }^{10}$. Mowa tu jednak o grodach położonych zwykle na krawędziach form terenowych, ponad dolinami rzek lub na krawędziach płaskowyżów. W przypadku grodziska Valy wskazać należy jednak na jego znaczne oddalenie od krawędzi doliny, które czyni je grodziskiem w istocie wyżynnym, położonym dość głęboko wśród wzgórz.

Całą aglomerację Bojnej tworzy sześć obiektów obronnych. Są to sąsiadujące z Valami od południowego wschodu grodzisko Bojná III Žihl'avník, położone dalej na północ na tym samym wzgórzu Bojná V Halšiny, poprzeczne umocnienia Bojná IV Nové valy, grodzisko Bojná II Hradisko zamykające wstęp do wąwozu rzeczki Bojnianki, grodzisko Hubina-Marhat usytuowane na najwyższym szczycie Považskiego Inovca (748 m n.p.m.) oraz niewielki gródek położony u jego południowych stóp w Vozokanach. Do stworzonej w ten sposób sieci umocnień doliczyć należałoby jeszcze grodzisko znajdujące się na szczycie Úhradu (645 m n.p.m.) - góry sąsiadującej z wzniesieniem Bojná II Hradisko - a także tzw. pański dwór w Nitrianskiej Blatnicy, który, choć grodziskiem nie byl, z pewnością stanowił ufortyfikowany, chociażby tylko palisadą, punkt ${ }^{11}$.

storicko-vlastivedná monografia, red. V. Uhlár, Topol'čany 1988, s. 45, wspomina o rzekomym znalezisku wielkomorawskich pochówków przy kopaniu rurociągu we wsi Malé Dvorany (obecnie część wsi Bojná). Nie ma na to jednak żadnych dowodów. W miejscu rzekomego znaleziska (notabene tuż za ogrodzeniem bazy wykopaliskowej AÚ SAV) nie udało się natrafić na żadne ślady wczesnośredniowiecznego osadnictwa.

10 M. Parczewski, Początki ksztaltowania się polsko-ruskiej rubieży etnicznej w Karpatach. U źródeł rozpadu Stowiańszczyzny na odłam wschodni i zachodni, Kraków 1991; J. Poleski, Małopolska w VI-X wieku. Studium archeologiczne, Kraków 2013.

11 Datowanie czasu powstania przedromańskiej rotundy św. Juraja w tym miejscu jest ciągle przedmiotem debaty (por. M. Bóna, P. Barta, Príspevok $k$ datovaniu vzniku rotundy sv. Juraja v Nitrianskej Blatnici. Archaeologia historica 40 (2015), s. 683-689; J. Dorica, Predrománska Rotunda sv. Juraja pri Nitrianskej Blatnici vo svetle reštaurátorského výskumu a reštaurovania a jej nové zaradenie v kontexte najstarších sakralnych stavieb na Slovensku, [w:] Bojná 2, s. 281-296; M. Illáš, Nejasnosti v interpretácii niektorých nálezov v rotunde sv. Juraja v Nitrianskej Blatnici, Musaica archaeologica 2 (2017), s. 57-62; A. Ruttkay, Výskum Rotundy sv. Juraja v lesoch nad Nitrianskou Blatnicou a osídlenia mikroregionu v 9.-13. storočí, [w:] Bojná 2, s. 235-251. Sposób publikacji niezmiernie istotnych dat radiowęglowych szczątków 
Większość tych obiektów powstała w okresach pradziejowych - halsztackim bądź lateńskim - i została ponownie wykorzystana we wczesnym średniowieczu ${ }^{12}$, w okresie funkcjonowania grodziska Valy. Poświadczają to znaleziska militariów, głównie ostróg i elementów ich zapięć, a także broni w typie wielkomorawskim. Nie jest jasne, jak intensywne było to wykorzystywanie, czy wiązało się z zasadniczą odnową umocnień, czy tylko ich doraźnym przystosowaniem. Najprawdopodobniejsza jest hipoteza, że obiekty te służyły tylko jako umocnione punkty kontrolne, a główny punkt łańcucha umocnień i zapewne też ostateczne refugium stanowiło grodzisko Valy. Dojście do niego w miarę wygodną drogą z którejkolwiek strony (także od strony Wagu) wymagało minięcia przynajmniej jednego ze wspomnianych obiektów.

Niejasna pozostaje relacja grodziska Valy z położonym stosunkowo niedaleko $(15 \mathrm{~km})$ dużym grodziskiem w Pobedimiu i mniejszymi grodami w jego pobliżu. $\mathrm{W}$ świetle ostatnich analiz ${ }^{13}$ należy uznać, że gród w Pobedimiu funkcjonował od około połowy do końca IX w. Oba obiekty, Pobedim i Bojná-Valy, przynajmniej teoretycznie przez jakiś czas mogły działać równolegle. Pobedim jednak, jedyne w okolicy grodzisko nizinne, położony w rozlewisku Wagu, przy „magistrali” komunikacyjnej, jaką od pradziejów tworzyły ta rzeka i jej szeroka dolina, stanowił centrum aglomeracji poważskiej. W odróżnieniu od Bojnej był otoczony wianuszkiem osad i cmentarzysk oraz siecią grodzisk peryferyjnych, do których należy zaliczyć m.in. obiekty obronne w Ducovém, Hubinie i Hradku. Układ ten wydaje się tworzyć pewną zamkniętą koncepcję (centralny gród - osady; cmentarzyska - grody peryferyjne, w tym dwór pański i pojedyncze osady), której nie da się aplikować w przypadku lokalizacji grodziska Bojná-Valy. W wypadku aglomeracji środkowonitrzańskiej mamy bowiem centralnie

organicznych pobranych z lawy fundamentowej (P. Povinec, J. Dorica, Slovensko má stredoeurópsky unikát. Výskum ukázal skutočný vek historickej rotundy, https://history.hnonline.sk/ starsie-dejiny/1094864-slovensko-ma-stredoeuropsky-unikat-vyskum-ukazal-skutocny-vek-historickej-rotundy [dostęp: 15 XI 2019]) pozostawia wiele do życzenia.

12 Jak do tej pory nie udało się tylko datować umocnień Bojnej IV, nie jest też jasne, czy grodzisko na Žihl'avníku powstało we wczesnym średniowieczu, czy też jest prahistoryczne, a we wczesnym średniowieczu (najprawdopodobniej w VIII w.) zostało ponownie zasiedlone. Pomimo intensywnych badań umocnień przez kilka sezonów udało się uzyskać tylko jedną próbkę węgla do datowania C14. Opieranie się na niej nie może być decydujące bez uzyskania innych wyników do porównania.

13 P. Bednár, M. Ruttkay, Nitra and the Principality of Nitra after the Fall of Great Moravia, [w: Moravian and Silesian Strongholds of the Tenth and Eleventh Centuries in the Context of Central Europe, ed. by P. Kouril, R. Procházka, Brno 2018, s. 229-244, tu s. 240-241; Z. Robak, The Sword and Sword-belt, s. 162. 
zlokalizowane osady (skupiska w rejonie ujścia Bebravy do Nitry), grodziska posadowione na krawędzi wysoczyzny (także na południowo-wschodniej krawędzi), prawdopodobnie pański dwór w Nitrianskej Blatnicy ${ }^{14}$, ale największy, rzekomo główny, obiekt jest położony na samym skraju tego układu osadniczego w dość niedostępnym miejscu. Warunkom osadniczym i sposobowi funkcjonowania Pobedimia odpowiada raczej położenie Nitry ${ }^{15}$. Mamy tu bowiem do czynienia z tzw. miastem grodowym, zjawiskiem typowym dla osadnictwa kultury wielkomorawskiej. Kompleksy takie powstawały w miejscach, w których możliwy był w miarę nieskrępowany rozwój osadnictwa otwartego otaczającego gród (dający się zwykle prześledzić archeologicznie wstecz do czasów sprzed powstania grodu), zwykle w szerokich dolinach lub na nizinie, na wyspach w rozlewisku dużej rzeki, a dogodna komunikacja i zarządzanie przestrzenią stanowily priorytet przed warunkami obronnymi ${ }^{16}$. Do takich „miast grodowych” zaliczyć można przede wszystkim, oprócz wspomnianych Nitry i Pobedimia, Mikulčice, Staré Město i Břeclav-Pohansko. Bojná-Valy różni się od nich diametralnie.

Optyka jednak się zmienia, jeżeli będziemy rozpatrywać grodzisko Bojná-Valy jako obiekt stricte militarny, a nie centrum polityczno-administracyjno-gospodarcze regionu, za które zostało uznane niedługo po odkryciu. W takiej sytuacji jego położenie w górach, na samej granicy geograficznej dwóch mikroregionów, ma sens, gdyż dostęp do grodu jest chroniony przez obiekty „krawędziowe” zarówno skupiska środkowonitrzańskiego, jak i poważskiego. Układ militarny spajałby w ten sposób dwa układy osadnicze. Ewentualny „antagonizm” socjoekonomiczny dwóch mikroregionów nie miałby tu już wielkiego znaczenia, gdyż oba funkcjonowały w ramach jednej organizacji politycznej i militarnej.

\section{Umocnienia grodziska}

Wały grodziska Valy zachowane są w bardzo dobrym stanie i doskonale widoczne na zdjęciach lotniczych oraz skanach Lidar (ryc. 3). Przypuszczalnie ich wysokość jest

\footnotetext{
14 A. Ruttkay, Výskum Rotundy, s. 235-251.

15 P. Bednár, M. Ruttkay, Nitra and the Principality, Brno 2018.

16 G. Fusek, Die Nebenareale in der Struktur der großmährischen Burgstadt von Nitra, [w:] Burg - Vorburg - Suburbium. Zur Problematik der Nebenareale frühmittelalterlicher Zentren. Internationale Tagungen in Mikulčice 7, hrsg. v. I. Boháčová, L. Poláček, Brno 2008, s. 276; T. König, The Great Moravian territory of Nitra: Cultural manifestations, territorial scope and the ethnic and social-political identity of its population, Muzeológia a kultúrne dedičstvo 5 (2017), nr 2, s. 9-28, tu s. 14-17.
} 
bliska oryginalnej wysokości nasypów. Na zdjęciach Lidar są znakomicie widoczne także przemiany w topografii zboczy wzgórza spowodowane czerpaniem materiału na wypełniska komór. Główne umocnienia były badane wykopaliskowo w czterech miejscach (trzy cięcia wału oraz wschodnia brama), a wał chroniący podgrodzie w dwóch. Rozpoznanie archeologiczne pozwoliło na wysnucie kilku interesujących wniosków dotyczących konstrukcji umocnień ${ }^{17}$.

Wał w rejonie zachodniej bramy był skonstruowany w najbardziej skomplikowany sposób. Konstrukcję komorową wspierał typowy dla wielkomorawskiego budownictwa obronnego suchy mur z kamieni. Wał miał u podstawy szerokość około $7 \mathrm{~m}$, przy koronie około $5 \mathrm{~m}$. Zachował się do wysokości nieco ponad $4 \mathrm{~m}$, licząc od wewnątrz. Przed wałem znajdowała się fosa o głębokości około $2 \mathrm{~m}$, a przed nią niewielki nasyp powstały w wyniku wybrania ziemi z fosy. Można przypuszczać, że pierwotnie znajdowała się na nim palisada lub częstokół.

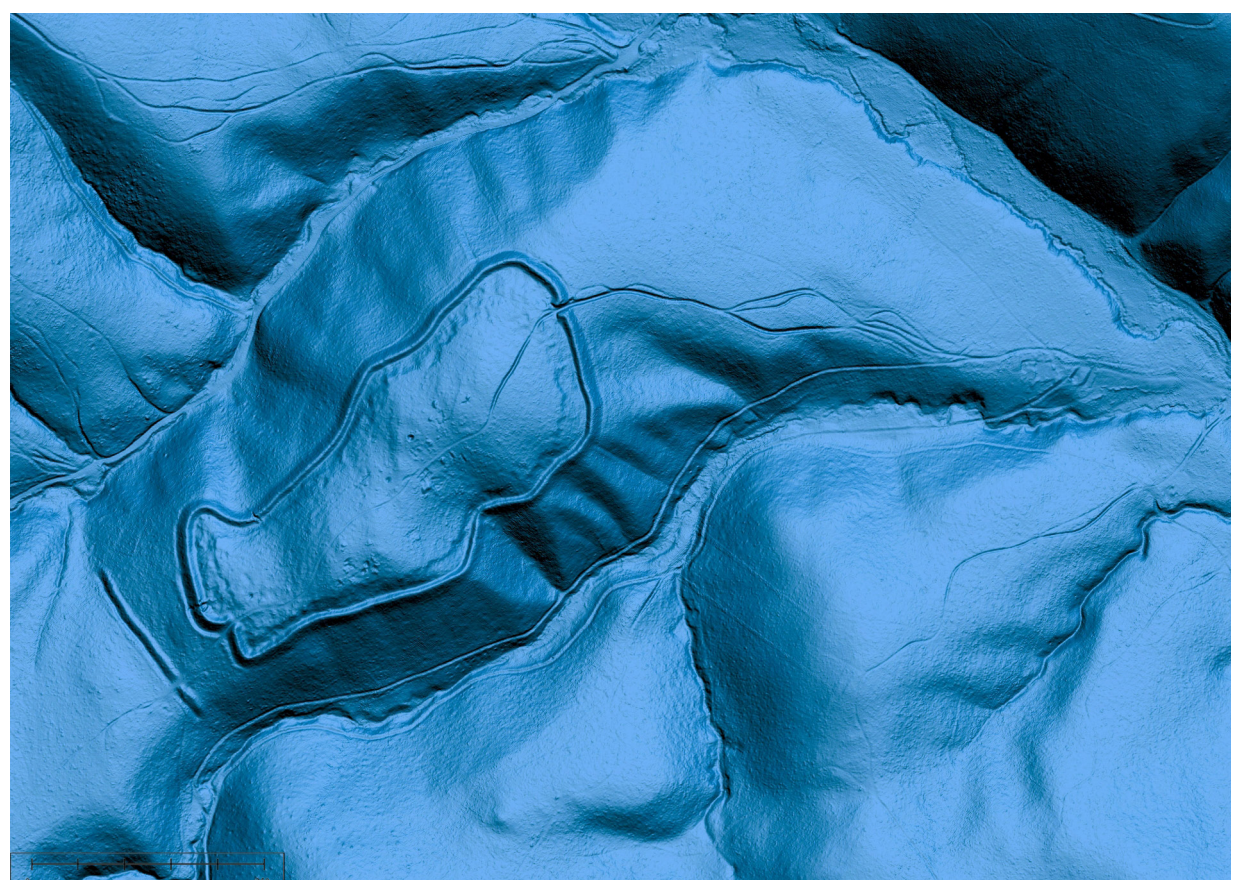

Ryc. 3. Bojná-Valy. Trójwymiarowy model terenu z widocznymi liniami wałów

17 Por. K. Pieta, Včasnostredoveké mocenské centrum, Nitra 2017; K. Pieta, Z. Robak, The Early Medieval, s. 329-351. 
Ze względu na spadek terenu fundament konstrukcji tworzyła gliniana ława niwelująca poziom. Na niej była posadowiona warstwa dość sporych kamieni z ziemią, a dopiero na niej nieco węższa konstrukcja komorowa. Komory przeważnie miały długość około 5,5 m. Boczne ściany komór o wys. około 3,5 m, skonstruowano w ten sposób, że belki ułożone jedna na drugiej były klinowane przez dwie pary słupów wkopanych głęboko w podłoże ${ }^{18}$, a boki ścian były obłożone kamieniami. Górną krawędź takiej ściany zamiast belki tworzyły kamienie w rzędzie lub kilku warstwach. Lico wewnętrzne u podstawy stanowiła plecionka $\mathrm{z}$ dość grubych prętów wsparta kamiennym murkiem, a u komory tylko plecionka. Przypuszczalnie plecionka wzmacniała też ścianę zewnętrzną komór, którą następnie na całej wysokości komory i podstawy tworzył suchy mur. Wnętrze komory składało się z ziemi przemieszanej z drobniejszymi kamieniami. Warstwy co kilkadziesiąt centymetrów były przedzielane drewnianym rusztem.

Wał zamykający podgrodzie od zachodu był prostym nasypem ziemnym o wysokości około 2,5 m i szerokości $8 \mathrm{~m}$, którego ściany wewnętrzną i zewnętrzną pierwotnie zapewne tworzyły plecionka lub konstrukcja w rodzaju płotu wzmacniana kamieniami. Nasyp zachował się do wysokości 2,5 m. Głównym elementem obronnym była tu jednak fosa w kształcie klina o bardzo stromych ścianach, o głębokości przekraczającej $2 \mathrm{~m}$ i szerokości około $3 \mathrm{~m}$. Na dnie fosy odnaleziono resztki drewnianej konstrukcji - palisady z wału, ściany lub częstokołu. W rejonie bramy przejazd jest sztucznie poszerzony, co oznacza, że brama wału podgrodzia została zniszczona, prawdopodobnie już współcześnie, przy okazji prac leśnych. Nie odnaleziono natomiast śladów umocnień na północnym i południowym skrajach podgrodzia. Wał kończy się na krawędziach wąwozów. Trudno jednak wyobrazić sobie, aby zamiarem budowniczych było pozostawienie przestrzeni otwartej w ten sposób. Najprawdopo-

18 Druga interpretacja (K. Pieta, Včasnostredoveké mocenské centrum, s. 20-21) zakłada, że ściany komór sięgały dna, tzn. w jakiś sposób rozdzielały warstwę niwelującą z podstawą, co by sugerował inny wykop. Jest to możliwe, aczkolwiek w dolnych partiach wału ściany komór nie są czytelne (albo nie zachowały się, albo ich nie było), trudno zatem rozstrzygnąć bez dalszych badań. Niemniej jednak jedna para słupów badanej komory była wkopana w warstwę kamieni stanowiącą bazę i w miejscu tym nie zarejestrowano nieciągłości tejże warstwy. Taka przerwa, gdyby wystąpiła, mogłaby sugerować styk dwóch komór. Stąd hipoteza o ciągłej podstawie wału, przynajmniej w badanym miejscu. Wysoce prawdopodobne, że poszczególne komory różniły się detalami albo że podstawa między przerwami konstrukcyjnymi nosiła więcej niż jedną komorę. Nie jest wykluczone, choć to tylko hipoteza, że masywna kamienna podstawa przebadanej komory miała dźwigać jakąś dodatkową konstrukcję, np. wieżę. 
dobniej ścianę tworzyła tu zwykła palisada, co mogło być wystarczające, zważywszy na znaczny spadek terenu w rejonie ścian wąwozów.

Wschodni wał grodziska, przynajmniej w rejonie bramy, także skonstruowany był w technice komorowej, z kamienno-drewnianymi ścianami komór, a jego ścianę zewnętrzną i wewnętrzną tworzyła plecionka. Powtarza się piętrowy sposób konstrukcji wału znany ze ściany zachodniej - nieco szersza, masywna podstawa (czoło północnego skrzydła dodatkowo na warstwie niwelacyjnej) i węższe komory z warstwami rusztów, mniej więcej od połowy wysokości wału. Wypełniska komór i podstawa zawierają jednakże mało dużych kamieni. Nie natrafiono tu także na pozostałości suchego muru. Głębokość fosy w rejonie bramy sięga $2 \mathrm{~m}$. Badania wału w dalszej części wschodniej ściany, na północ od bramy, nie dały jednoznacznych wyników co do sposobu konstrukcji, gdyż nie natrafiono wówczas na ścianę komory, ale przypuszczalnie i ta partia umocnień była utworzona w podobny sposób. Ściany zewnętrzną i wewnętrzną wschodniego wału tworzyły plecionki z grubych prętów (z zewnątrz osobna dla podstawy i osadzona na niej druga, dla komory), a wypełnisko wyłącznie ziemia. Jedynie fosa jest bardzo płytka, jej głębokość nie przekraczała $1 \mathrm{~m}$. Nie wiadomo, czy był to zamierzony efekt, czy też wał wschodni nie został wykończony (co tłumaczyłoby i brak suchego muru, i dwie linie plecionek).

Odmienna konstrukcja cechowała umocnienia w północno-zachodnim fragmencie grodziska, tam, gdzie wał biegł wzdłuż stromego zbocza wzniesienia. Zastosowano tu prostą konstrukcję przekładkową w postaci nasypu ziemnego (miejscami zwietrzałej skały) przekładanego kilkoma warstwami rusztów (w dolnych partiach dwukierunkowego, w górnych tylko poprzecznie do linii wału). Warstwy sypane były tak, aby przed położeniem rusztu uzyskać poziom. Nie zachowały się żadne elementy licujące ściany, należy jednak zauważyć, że spaleniu uległy tu tylko górne partie wału, tzn. najwyższa przekładka, natomiast elementy organiczne w dolnych partiach zbutwiały). Szerokość wału wynosiła w tym miejscu około $8 \mathrm{~m}$ (trudno mówić o podstawie, gdyż usypano go na zboczu), ale wysokość wewnętrzna tylko około 2,5 m (od zewnątrz dawało to około 4,5 m wysokości). Konstrukcja wału była trudna statycznie ze względu na położenie na stromych zboczach. Jednocześnie należy przypuszczać, że na odcinkach północnym i południowym wał mógł mieć uproszczoną konstrukcję, gdyż strome zbocza i przepływające u ich podnóży potoki skutecznie zniechęcały do wspinaczki w tym miejscu.

Bramy grodziska tworzyły przejścia w formie zagiętych do wnętrza grodu kleszczy, lekko rozszerzonych u wejścia. Zachowały się do wysokości około 4,5 m, licząc od pierwotnego poziomu terenu (dziś wąwóz jest głębszy). Szerokość światła 
wschodniej bramy sięgała 4,5-4,6 m, a długość korytarza - prawie $12 \mathrm{~m}$. Brama zachodnia miała podobne rozmiary, choć ze względu na położenie na osi grzbietu wzgórza wydaje się mniejsza.

Zdecydowanie największe wrażenie musiały robić umocnienia zachodniego odcinka wału, które wraz z wykutą w skale zewnętrzną fosą jeszcze dziś mierzą 7,2 m wysokości. Wraz z niezachowaną koroną i przypuszczalnie palisadą na szczycie wału ściana zewnętrzna mogła mierzyć 9-10 m. Podobną wysokość miał wał odcinka wschodniego, pomimo że fosa była o wiele płytsza.

\section{Zagospodarowanie}

Powierzchnia grodziska została przebadana w około $5 \%$, stąd daleko idące wnioski dotyczące zabudowy i zagospodarowania terenu są przedwczesne. Regularne badania majdanu skupily się na obszarach zdatnych pod zabudowę - tzw. akropolu, czyli najwyżej położonej części grodziska, szerokim wypłaszczeniu wzgórza w jego środkowej części, a także na zachodnim podgrodziu. Inne obszary były badane sondażowo relatywnie niewielkimi wykopami.

Do tej pory na grodzisku odkryto 13 obiektów mieszkalnych, jeden nieznanego przeznaczenia oraz dwa obiekty interpretowane jako pracownie. Formy budynków są dość dobrze czytelne (w Bojnej półziemianki zostały wykute w zwietrzałej skale), w części obiektów mieszkalnych piec nie jest zniszczony lub zniszczony w stosunkowo małym stopniu. Niemal w każdej półziemiance są znajdowane całe naczynia oraz inne przedmioty zalegające na jej dnie. Ogólnie obiekty mieszkalne sprawiają raczej wrażenie porzuconych i zniszczałych $w$ trakcie naturalnych procesów podepozycyjnych. Żaden z obiektów nie uległ zniszczeniu w trakcie pożaru (w jednym wypadku ziemianka została intencjonalnie zasypana).

Zarówno najwyżej położona część grodziska (wspomniany akropol), jak i rozległe wypłaszczenie pośrodku wschodniej części wzgórza objęte były zabudową mieszkalną. Na obszarze tym odnaleziono jak dotąd pozostałości 11 budynków. Dziesięć z nich to pozostałości typowych dla wczesnośredniowiecznych kultur Słowian półziemianek - zagłębionych w grunt czworokątnych budynków o powierzchni $9-11 \mathrm{~m}^{2} \mathrm{z}$ pozostałościami kamiennego pieca w jednym z narożników. Wyjątkowo na tym tle prezentuje się jedenasty z odkrytych budynków. Stanowił on prawdopodobnie budynek naziemny o rozmiarach około 2,5 × 3,5 m. Zachował się z niego wyłącznie ślad zadokumentowany na powierzchni odkrytego wykopu. Nie wiadomo, czy służył jako obiekt mieszkalny. 
Jak się wydaje, na centralnym wypłaszczeniu półziemianki były ulokowane w linii ciągnącej się wzdłuż obecnej drogi przebiegającej przez wzgórze (w przeszłości zapewne ciąg komunikacyjny przebiegał podobnie). Nie wiadomo, jak wyglądała zabudowa zachodniej części wzgórza, ale w pobliżu zachodniej bramy także odkryto pozostałości półziemianki. Można zatem przypuszczać (wnosząc także z ukształtowania terenu), że zabudowa mieszkalna ciągnęła się liniowo przez całe grodzisko, z grubsza wzdłuż dzisiejszej drogi.

W centralnej części grodziska, pomiędzy „akropolem” a zabudową na wypłaszczeniu, odkryto pozostałości dużego wolnostojącego pieca z glinianą kopułą, a opodal warstwę zawierającą przepaloną glinę i fragmenty prażnic. Strefa ta jest interpretowana jako strefa działalności gospodarczej związanej z przygotowywaniem żywności. Wolnostojący piec z glinianą kopułą, choć mniejszy, odkryto także na „akropolu”, w tym wypadku może jednak chodzić o piec zniszczonego obiektu. Dwa podobne znaleziono także w obiekcie przylegającym do jednej z półziemianek we wschodniej części grodziska.

W pobliżu niektórych półziemianek odkryto owalne jamy dużych rozmiarów z płaskimi dnami. Stanowią one pozostałości piwniczek lub podobnych obiektów służących do przechowywania żywności. W większości odnaleziono pozostałości ziaren zbóż lub roślin strączkowych. Zespół kilku prostokątnych jam o płaskim dnie odsłonięto także w południowo-wschodniej części grodziska. Ponieważ w pobliżu nie znaleziono śladów żadnej ziemianki, strefa ta interpretowana jest jako strefa jam gospodarczych. Znaleziska pochodzące z obiektów (ziarna zbóż, całe naczynia, grzywny siekieropodobne) świadczą o tym, że chodzi o obiekty w rodzaju piwniczki lub składu. Należy przy tym zauważyć, że analizy wypełnisk obiektów nie wykazały śladów plew.

Interesująco przedstawia się kwestia zagospodarowania umocnionego zachodniego podgrodzia. Jego południowa część wydaje się pozostawać wolna od śladów zabudowy - nie zarejestrowano tam żadnego wczesnośredniowiecznego obiektu - a jedynym wyjątkiem był sporych rozmiarów obiekt (prawdopodobnie pozostałość budynku mieszkalnego) datowany na epokę brązu. Obiekt nie był zniszczony, pomimo że w górnych warstwach zalegała wczesnośredniowieczna ceramika. Potwierdza to obserwację, że ta część grodziska nie była we wczesnym średniowieczu intensywnie zagospodarowywana (sugeruje też, że inne obiekty pradziejowe mogły zostać zniszczone przez wczesnośredniowieczne osadnictwo).

Zgoła inaczej rysuje się obraz zagospodarowania północnej części podgrodzia. W pobliżu bramy odsłonięto pozostałości dużego obiektu o regularnym, prostokątnym zarysie, wokół którego zebrano kilkaset fragmentów żużla żelaznego. Suge- 
rowałoby to jakąś działalność gospodarczą związaną z obróbką żelaza, pomimo że w samym obiekcie nie zarejestrowano śladów paleniska. Na pozostałym przebadanym obszarze północnej części podgrodzia odnaleziono bardzo dobrze zachowane pozostałości dwóch półziemianek oraz dużą, prostokątną piwniczkę, na której dnie zachowała się spalona podłoga z dranic. Obszar ten zatem także był objęty zabudową mieszkalną.

Wnioski, które można wysnuć z analizy charakteru zabudowy grodziska, to przede wszystkim duża jednorodność zabudowy, jej egalitarny charakter (obiekty mieszkalne są niemal identyczne) i brak śladów jakiejkolwiek innej zabudowy ${ }^{19}$ (poza jednym budynkiem naziemnym, który rozmiarami nie odstaje od półziemianek), zwłaszcza śladów większych budynków o charakterze reprezentacyjnym. Oczywiście stopień przebadania obiektu jest relatywnie mały, jednakże wydaje się, że przebadano już obszary, gdzie takie budynki mogłyby się znajdować bez szkody dla ich stabilności ${ }^{20}$.

\section{Kultura materialna}

Cechą charakterystyczną grodziska Bojná-Valy jest ogromna ilość znalezisk zabytków, zwłaszcza przedmiotów metalowych ${ }^{21}$. Nieznana, choć przypuszczalnie duża liczba zabytków została zrabowana przez złodziei posługujących się wykrywaczami metali, którzy dewastowali obiekt przed rozpoczęciem badań archeologicznych i w pierwszych sezonach wykopalisk.

19 W starszych publikacjach można spotkać informacje o prawdopodobnym dużym budynku halowym z kamienną podmurówką. Hipoteza ta nie znajduje potwierdzenia w nowszych badaniach. Obiekt, który był tak interpretowany na początku badań na Bojnej, był pochodzenia naturalnego, a przypadkowe skupisko kamieni i tzw. pegmatytowych żył utworzyło koncentrację o prostokątnym kształcie. Stopień nachylenia terenu we wspomnianym miejscu wyklucza funkcjonowanie tu budynku o takich rozmiarach. Późniejsze badania wykazały, że pegmatytowe żyły i zwietrzałe fragmenty skał tworzą na wzgórzu formacje, które przypominają pozostałości działalności ludzkiej.

20 Dotyczy to zwłaszcza domniemanego budynku kaplicy/kościoła, którego nie odnaleziono. Zważywszy na to, że nigdzie w warstwach nie natrafiono na ślady zaprawy, budynek taki (jeśli istniał) był raczej drewniany i niewielki.

21 W latach 2005-2020 włącznie było to 6047 skatalogowanych zabytków wydzielonych, z których większość to przedmioty wykonane z żelaza. Doliczyć należy 303 przedmioty przechowywane w SNM w Bratysławie (V. Turčan, Depoty z Bojnej a včasnostredoveké hromadné nálezy železných predmetov uložené v zbierkach SNM-Archeologického muzea, Bratislava 2012). Ogół znalezisk nie został do tej pory opracowany. 
Zabytki odzwierciedlają niemal wszystkie aspekty życia wczesnośredniowiecznych mieszkańców grodu. Już na pierwszy rzut oka ilościowo wybijają się przedmioty związane ze strojem, wyposażeniem i uzbrojeniem wojowników. $Z$ terenu grodziska i jego najbliższych okolic pochodzi około 200 okuć rzemieni różnych rozmiarów i kształtu, w tym kilkanaście elementów garniturów mieczowych, ponad 130 sprzączek różnej wielkości, około 70 ostróg różnych typów i ponad 50 przewleczek. $\mathrm{Z}$ broni należy wymienić liczne znaleziska toporów (w tym bradatic), oszczepów oraz ponad 200 grotów strzał, z których około połowy to tzw. groty deltoidalne. Uzbrojenie ochronne reprezentują fragmenty kolczug, w tym jeden fragment składający się z kółek żelaznych i mosiężnych, prawdopodobnie pierwotnie tworzących wzór. Ponadto odnaleziono jak dotąd 15 wędzideł oraz dwa całe strzemiona i kilka fragmentów następnych. Do unikatowych znalezisk należą natomiast zdobiony trzewik pochwy miecza, okucie noża bojowego oraz hełm (niestety skradziony, znany jedynie $\mathrm{z}$ fotografii, stąd o niepewnym do końca pochodzeniu).

Zwraca uwagę średnia lub wręcz mizerna estetyka wykonania ozdób rzemieni stanowiących ozdoby stroju i elementy wyposażenia wojownika. W całym zbiorze setek zabytków zaliczanych do tej kategorii (okucia końca rzemienia, przewleczki, sprzączki itd.) znikoma jest liczba przedmiotów, które można uznać za elitarne, tzn. zdobione, wykonane z użyciem metali kolorowych lub szlachetnych. Co więcej, nawet wówczas, gdy przedmioty takie zidentyfikujemy, widać wyraźnie, że ich „elitarność” ( w porównaniu na przykład z przedmiotami stanowiącymi wyposażenie pochówków ze Starégo Města, Mikulčic czy Břeclavia-Pohanska) jest co najwyżej średnia. Brak tu przedmiotów wykonanych z użyciem metali szlachetnych i ozdobnych kamieni. Poza jednym okuciem rzemienia odlanym z brązu i stanowiącym zresztą wyrób masowy ${ }^{22}$ wszystkie elementy zapięć rzemieni, a także ostrogi są wykonane z żelaza. Ich ozdobę stanowi dość prosty ornament geometryczny, a w najlepszym przypadku miedziana lub, jak się okazało, mosiężna folia (w starszych publikacjach opisywana jako złota). Zauważalna jest także duża unifikacja wyrobów - całe serie przedmiotów, zwłaszcza okuć rzemieni, wyglądają jak wykonane w jednym warsztacie lub według jednego modelu.

Ogromna część znalezisk to narzędzia rolnicze oraz rzemieślnicze. Przedstawiają całe spektrum wyrobów, począwszy od narzędzi kowalskich (kowadła, duże młot-

22 Z. Robak, A comparative analysis of three fittings decorated with the Carolingian plant style coming from Mikulčice, Bojná and Zalavár, [w:] Beatus homo qui invenit sapientiam. Ünnepi kötet Tomka Péter 75. születésnapjára, szerk. T. Csécs, M. Takács, Györ 2016, s. 617-623. 
ki, szczypce), przez narzędzia do obróbki drewna (dłuta, wiertła, kliny, ciosła itp.), narzędzia rolnicze (radlice, kroje płużne, sierpy, półkoski), domowo-warsztatowe (nożyce, przekłuwacze, igły, szydła itd.), wreszcie drobne narzędzia jubilerskie (mały młoteczek, punca). Należy przy tym zauważyć, że działalność metalurgiczna, zwłaszcza kowalska, jest w materiale zabytkowym bardzo wyraźnie czytelna. Potwierdzają ją także znaleziska koncentracji żużla oraz półproduktów takich jak np. grzywien siekieropodobnych w początkowych stadiach przekuwania.

Dla grodziska Bojná-Valy typowe są także znaleziska depozytów przedmiotów żelaznych. Do tej pory na grodzisku i w bezpośrednim otoczeniu umocnień odnaleziono 30 takich zespołów. Składają się w większości z narzędzi rolniczych, rzemieślniczych, grzywien siekieropodobnych oraz elementów wyposażenia i uzbrojenia jeźdźca. Wyjątkowym znaleziskiem jest depozyt zawierający prawdopodobnie części wozu, jedyny zresztą znaleziony po zewnętrznej stronie umocnień (ryc. 4). Znane są także depozyty składające się tylko z narzędzi bądź tylko z ostróg.

30 depozytów na pierwszy rzut oka rzeczywiście może świadczyć o tym, że było to dobre miejsce do chowania majątku w czasie niebezpieczeństwa. W wypadku takiej twierdzy, jaką były Valy, to raczej oczywista obserwacja. Liczba depozytów budzi podziw, skłania jednak do zastanowienia się, czy we wszystkich przypadkach mamy rzeczywiście do czynienia $\mathrm{z}$ depozytami w powszechnym rozumieniu tego słowa, tzn. przedmiotami celowo zdeponowanymi w ziemi w celu ukrycia ich przed rabunkiem w chwilach grozy (lub też w celach kultowych). Wydaje się, że część zespołów odnaleziona w rozwalisku wału mogła być po prostu przechowywana $\mathrm{w}$ pomieszczeniach przylegających do umocnień albo w niewypełnionych komorach stanowiących rodzaj komórek i tam też pozostały. Znaleziska niektórych kompletów narzędzi lub broni (np. osiem ostróg) mogły leżeć w miejscach, w których po prostu pierwotnie je składowano, a pozostałości owych „miejsc” są już nieczytelne ${ }^{23}$. Niewątpliwie niektóre z depozytów były jednak majątkiem schowanym w chwili niebezpieczeństwa jak na przykład skarb 37 grzywien siekieropodobnych i kilku innych przedmiotów znaleziony w wyczyszczonym z popiołu piecu półziemianki (ryc. 5). Być może do takich należy też skarb pozłacanych plakiet pochodzących z relikwiarza lub ołtarza, który odnaleziono na południowym skraju zachodniego podgrodzia, oraz znalezisko dzwonu w nasypie wału.

23 Por. P. Dresler, V. Beran, Zemědělské nástroje raně středověkého obyvatelstva Pohanska u Břeclavi, Památky archeologické 110 (2019), s. 242-243. 


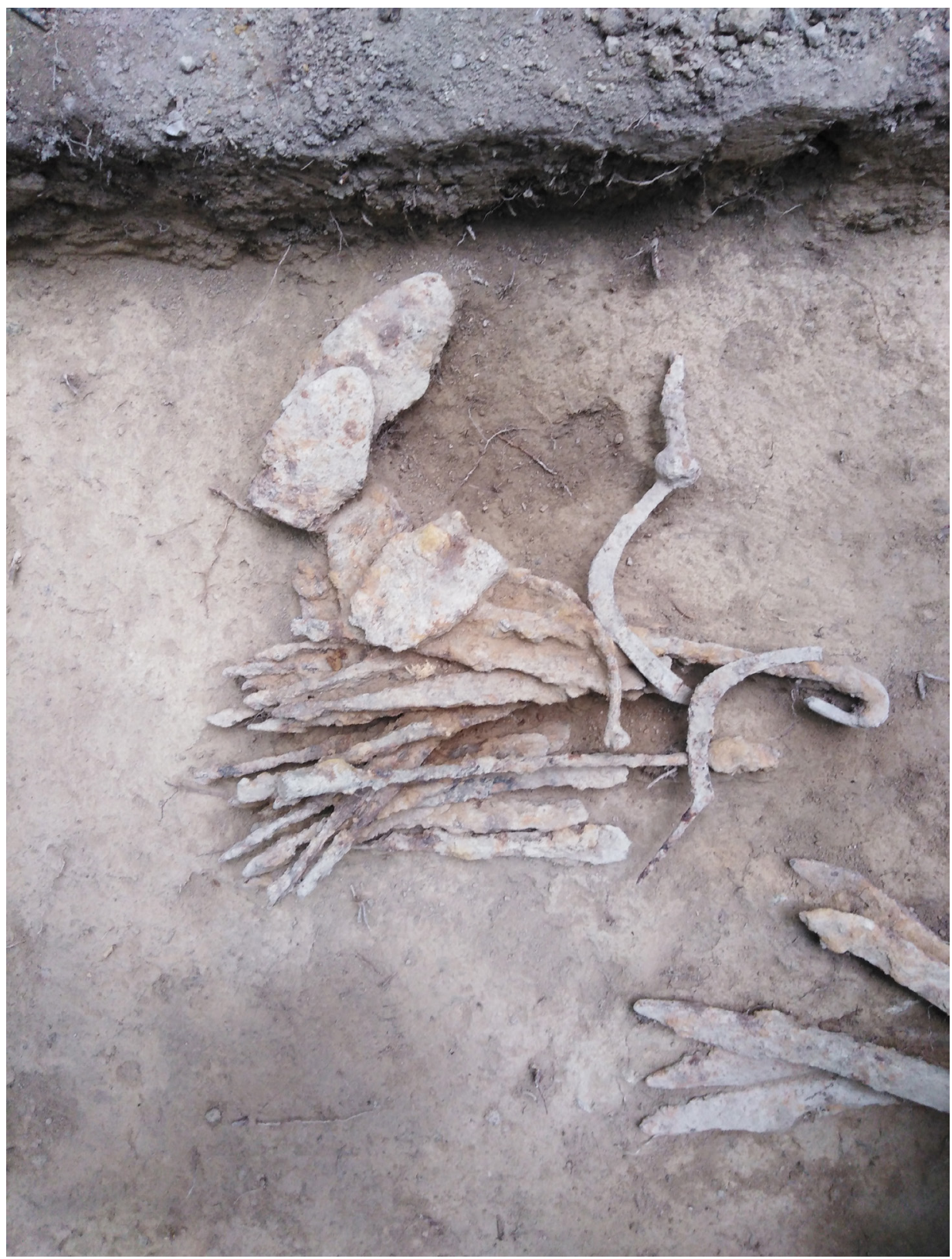

Ryc. 4. Depozyt przedmiotów żelaznych zawierający, oprócz narzędzi rolniczych i grzywien siekieropodobnych, prawdopodobnie części wozu (foto: Z. Robak/K. Pieta) 


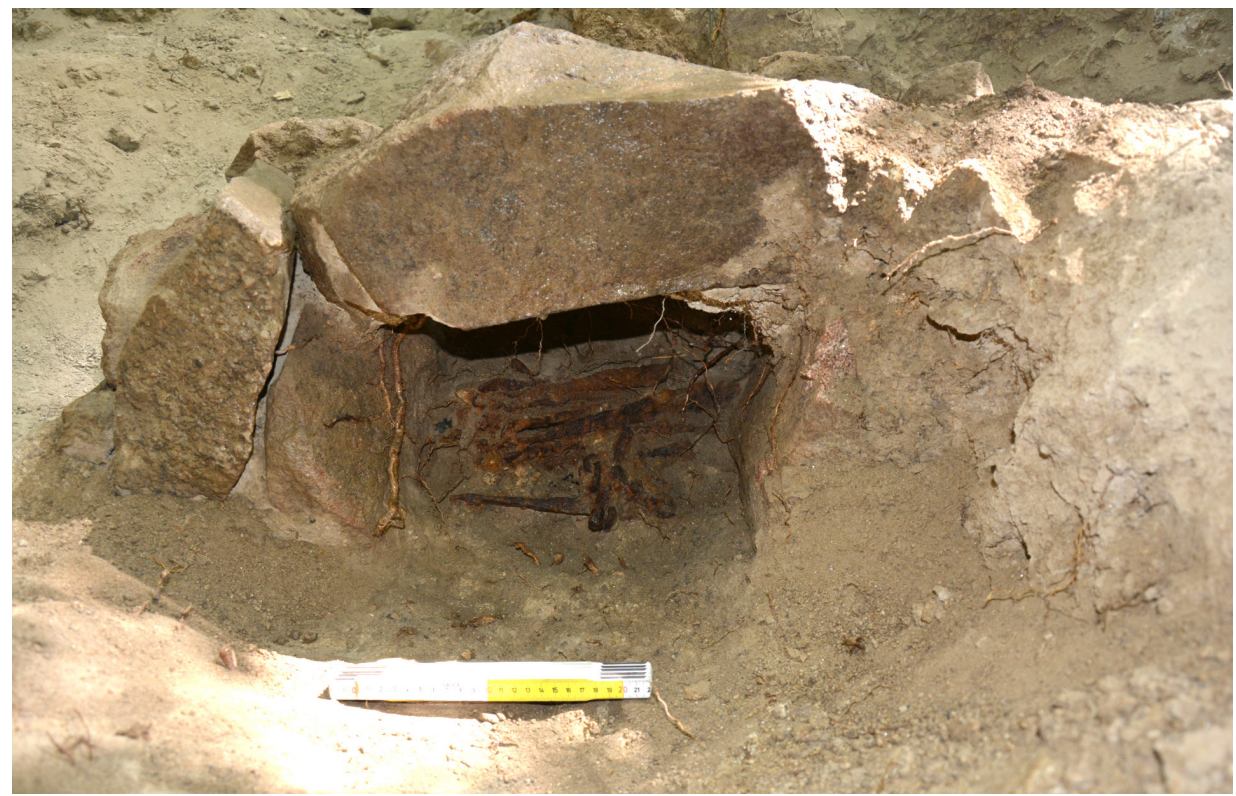

Ryc. 5. Skarb grzywien siekieropodobnych w piecu półziemianki (foto: Z. Robak/K. Pieta)

Zbiór militariów pochodzących z grodziska rzeczywiście jest wyjątkowy na skalę europejską (ryc. 6). Wrażenie robi nie tylko liczba znalezisk, lecz także mnogość typów i odmian elementów uzbrojenia i wyposażenia wojowników, np. kilku odmian okuć rzemieni nieznanych z innych stanowisk, a na stanowisku Valy występujących relatywnie często ${ }^{24}$. Niektóre elementy wyposażenia (np. ostrogi) noszą ślady napraw i przeróbek. Ta okoliczność, wraz z informacjami o aktywności metalurgicznej i kowalskiej na grodzisku, oraz powtarzalność niektórych typów ozdób, w dodatku nieznanych z innych stanowisk, pozwalają przypuszczać, że produkcja i naprawa tych przedmiotów odbywała się na miejscu, w lokalnych warsztatach. O powszechnej dostępności i niskiej cenie tych przedmiotów w grodzie niech świadczy wykorzystanie okucia, pochodzącego prawdopodobnie z garnituru okuć miecza, jako zastępczej ataszy wiadra.

24 Z. Robak, Studia nad okuciami rzemieni w typie karolińskim. VIII-X w. Część I, Nitra 2013, s. 181-185; tenże, The Age of Migrating Ideas: A Short Contribution on Cruciform Decorations on Great Moravian Strap Fitting in the $9^{\text {th }}$ Century, [w: Bewaffnung und Reiterausrüstung des 8. bis 10. Jahrhunderts in Mitteleuropa. Waffenform und Waffenbeigaben bei den mährischen Slawen und in den Nachbarländern, hrsg. v. L. Poláček, P. Kouřil, Brno 2019, s. $453-460$. 

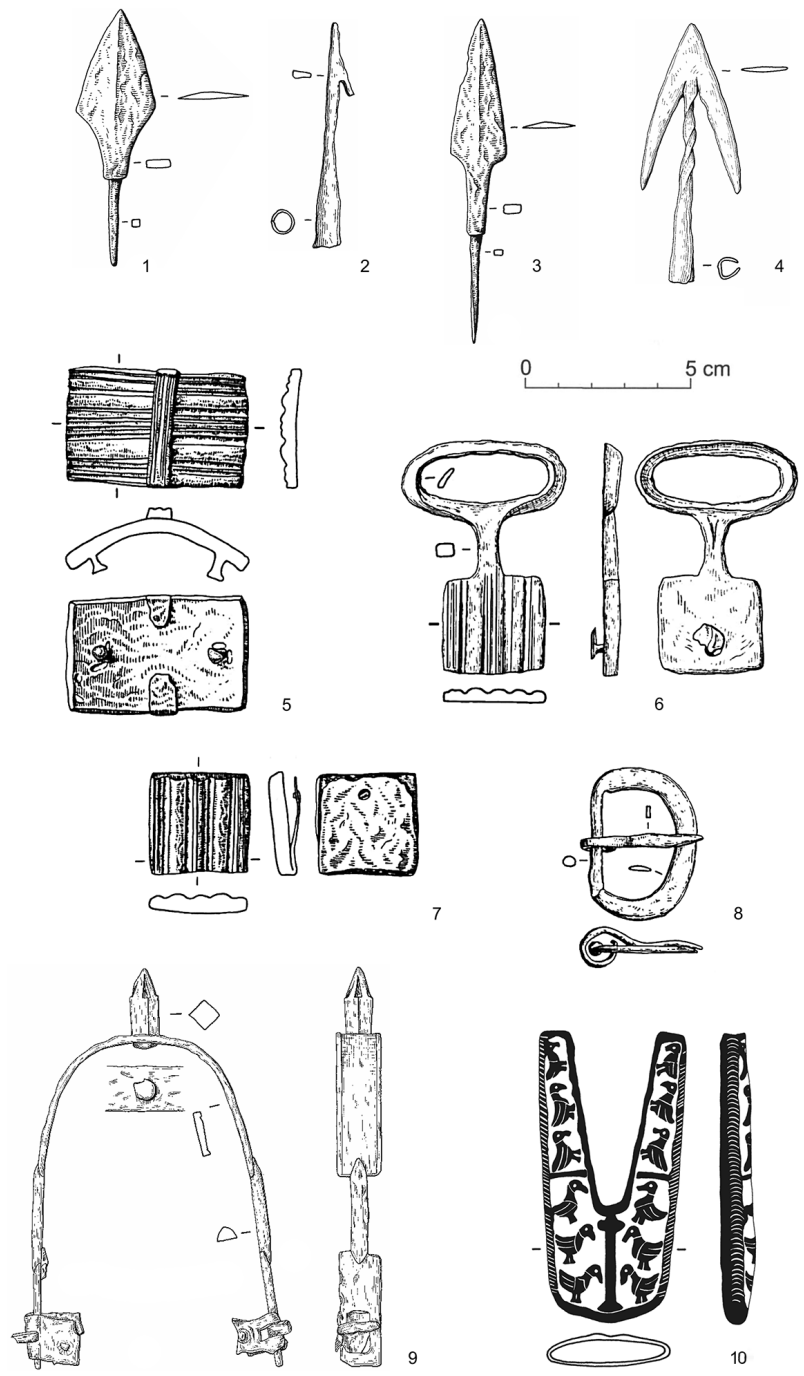

Ryc. 6. Militaria. 1-4: groty strzał; 5-8: garnitur okuć pasa mieczowego; 9: ostroga; 10: trzewik pochwy miecza. 1-9: żelazo; 10: żelazo, srebro (Archiwum AÚ SAV Nitra)

Materiał ceramiczny pochodzący z Valów jest bardzo liczny. W większości są to pozostałości naczyń garnkowatych. Do rzadkości należą znaleziska innych typów naczyń, jak np. talerz lub flasza, ale należy zauważyć, że materiał ceramiczny był poddany opracowaniu w niewielkim tylko stopniu. W obiektach, głównie na piecach półziemianek lub obok nich, a także w warstwie kulturowej bardzo często są znajdo- 
wane naczynia całe lub uszkodzone, ale dające się skleić w całość. Co interesujące, nie natrafiono na ślady działalności pracowni garncarskiej. Naczynia prezentują przy tym dość zróżnicowany zbiór pod względem form, co sugeruje, że naczynia w większości mogły być sprowadzane $\mathrm{z}$ innych miejsc ${ }^{25}$.

Z Bojnej pochodzą także dwa fragmenty szklanych naczyń ${ }^{26}$ podobne do fragmentów naczyń znajdowanych w elitarnych grobach w Mikulčicach oraz Kolinie, a także na terenach grodzisk w Břeclaviu-Pohansku, Břeclaviu-Nejdku, Ołomuńcu-Povlu oraz Starym Měste-Sadach ${ }^{27}$. Należy przy tym zauważyć, że ze wspominanych grodzisk pochodzą dziesiątki znalezisk szklanych fragmentów różnego typu pucharów, lamp, butli, szkieł interpretowanych jako okienne oraz tzw. gładzików.

W materiale zabytkowym wyraźnie dostrzegalny jest natomiast niemal zupełny brak ozdób. Poza fragmentem zausznicy gwiazdowatej oraz lunulą za ozdobny można uznać jeszcze szklany gombik, szklany koralik oraz wymieniony w inwentarzu posrebrzany gombik. Tych pięć przedmiotów wyczerpuje listę ozdób pochodzących z terenu grodziska (jeśli pominąć okucia rzemienia, które można uznać za ozdobę funkcjonalną).

\section{Stratygrafia i chronologia obiektu}

Grodzisko Bojná-Valy w tej formie, w jakiej się zachowało, powstało pod koniec IX w. Grodzisko Valy jest jedynym obiektem całego układu grodzisk w aglomeracji Bojnej powstałym, jak się wydaje, na „na surowym korzeniu”. W przeciwieństwie do pozostałych grodzisk nie odkryto na wzgórzu śladów intensywnego osadnictwa pradziejowego. W ciągu 14 sezonów badań wykopaliskowych odnaleziono zaledwie jeden obiekt prahistoryczny, datowany wstępnie na późną epokę brązu, oraz nieliczne fragmenty ceramiki z tego okresu w zasypisku pobliskiej fosy. Należy jednak zauważyć, że obiekt ten oraz fragmenty ceramiki znajdowały się w południowo-zachodniej części zachodniego podgrodzia, najmniej zmienionej przez osadnictwo wczesnośredniowieczne związane z grodem. Możliwe zatem, że ewentualne ślady

25 T. Vangl'ová, Včasnostredoveká keramika z hradiska Bojná I-Valy, Slovenská archeológia 68 (2020), s. 95-181.

26 Inwentarze zabytków z Bojnej zawierają jeszcze kilka fragmentów szkieł, jednakże bez analiz trudno określić, czy wszystkie to szkła wczesnośredniowieczne. Jedno z nich jest na przykład fragmentem lateńskiej bransolety.

27 L. Galuška, J. Macháček, K. Pieta, H. Sedláčková, The Glass of Great Moravia: Vessel and Window Glass, and Small Objects, Journal of Glass Studies 54 (2012), s. 61-92. 
starszego osadnictwa w centralnej części wzgórza zostały w większości unicestwione przez osadnictwo wczesnośredniowieczne.

Nie jest to przypuszczenie bezpodstawne. Obiekt, choć jest nieskomplikowany stratygraficznie, co stanowi ułatwienie przy prowadzeniu prac wykopaliskowych i dokumentacyjnych, przyprawia jednak o ból głowy podczas prób przedstawienia spójnej chronologii rozwoju osadnictwa na obszarze wzgórza Valy. Fenomenem grodziska jest bowiem niemal zupełny brak warstwy kulturowej na majdanie (poza wypełniskami obiektów) oraz brak relacji stratygraficznych pomiędzy obiektami. Superpozycje, z jednym wyjątkiem, nie są rejestrowane. Izolowane obiekty wkopane w skalne podłoże są pokryte zaledwie około 20-centymetrową warstwą leśnego humusu, w którym znajduje się ogromna ilość wczesnośredniowiecznych zabytków. Poza obiektami humus leśny zalega bezpośrednio nad podłożem. Jedynie w centralnej części południowego stoku zniszczone w górnych partiach wczesnośredniowieczne obiekty (jamy gospodarcze) były pokryte wczesnośredniowieczną warstwą kulturową. Na warstwę kulturową (organika z fragmentami ceramiki) natrafiono też pod pierwszą ławą niwelacyjną północno-wschodniego odcinka wału oraz w wąskim sondażu pod nasypem północnego skrzydła wschodniej bramy.

Jak wynika z dotychczasowych analiz wyników badań archeologicznych, na wzgórzu zachowały się ślady dwóch faz osadniczych i na podstawie analizy ogółu pozyskanego materiału archeologicznego można je obie łączyć jedynie z kulturą wielkomorawską ${ }^{28}$. Ułatwia to ustalenie ogólnej chronologii obiektu, którą można ramowo określić na pierwszą połowę IX - pierwszą połowę X w.

Obserwacje poczynione w trakcie eksploracji wału i majdanu sugerują, że przed budową umocnień obszar grodziska był użytkowany w sposób, który doprowadził do wytworzenia się warstwy kulturowej i że w trakcie użytkowania powstawały jakieś obiekty. Powstała warstwa kulturowa została następnie usunięta wraz z humusem pierwotnym i górnymi partiami zwietrzałej skały i użyta do budowy widocznych do dziś umocnień. Przy tej okazji zniszczono też starsze obiekty, a jedynie miejscami zachowały się dolne partie niektórych jam. Brak młodszej warstwy organiki na

\footnotetext{
28 Określenia „wielkomorawski” w tym kontekście używam wyłącznie w znaczeniu przymiotnikowym, jako określenie kultury materialnej charakterystycznej dla Słowian zamieszkujących obszary dzisiejszych Moraw i Słowacji pomiędzy przełomem pierwszej i drugiej ćwierci IX w. a pierwszą połową X w. Mam świadomość niefortunności tej nazwy wyprowadzonej od historycznego pojęcia Wielkich Moraw, oznaczającego konkretny organizm polityczny, którego czas istnienia i obszar niekoniecznie pokrywał się z czasem archeologicznym i obszarem przypisywanym kulturze materialnej.
} 
większości obszaru majdanu grodu należy tłumaczyć dość krótkim użytkowaniem grodu pomiędzy ukończeniem budowy wału a porzuceniem obiektu. Warstwa organiki związana z ostatnią fazą obiektu osadziła się jedynie w rejonie naturalnego „leja”, którym spływała wraz wodą deszczową i pokryła zniszczone, zasypane jamy.

Rozdzielenie i datowanie faz osadniczych wzgórza pozostaje na obecnym etapie badań jedynie w sferze hipotez. Starsza faza osadnictwa wczesnośredniowiecznego jest słabo czytelna. Nie jest możliwe stwierdzenie, czy istniały umocnienia wcześniejsze od zachowanych, związane $\mathrm{z}$ tą fazą ani jak ją precyzyjnie datować. Jedynym ułatwieniem jest to, że nie ma przesłanek pozwalających datować początki wczesnośredniowiecznego osadnictwa na wzgórzu na okres wcześniejszy niż pierwsza połowa (przy dużej dozie tolerancji może początek) IX w. ${ }^{29} \mathrm{Ze}$ starszą fazą osadniczą można łączyć część jam gospodarczych, które zachowały się w dolnych partiach oraz jedną półziemiankę, którą celowo zasypano, a zagłębienie wyrównano warstwą kamieni.

Części obiektów nie można przypisać do konkretnej fazy/faz. Analizy radiowęglowe wskazują co prawda na grupę obiektów mieszkalnych, które mogą być starsze od pozostałych, jednak seria próbek jest zbyt mała, aby w tym momencie wyciągać daleko idące wnioski. Być może trwające analizy radiowęglowe i duża seria dat pozwolą na uzyskanie czytelniejszego obrazu rozwarstwienia chronologicznego obiektów na grodzisku.

Chronologia ostatniej fazy osadniczej grodziska oparta jest na szeregu dat dendrochronologicznych drewna uzyskanego z wału głównego i wału podgrodzia (tab. 1). Większość dat dendro wskazuje na lata dziewięćdziesiąte IX w. jako okres pozyskiwania drewna. Można zatem przypuszczać, że do budowy tych potężnych umocnień przystąpiono u schyłku IX w. Z fazą tą wiązany jest zbiór zabytków pozyskanych z warstwy humusu i znikomej warstwy kulturowej na majdanie grodziska, a także obiekty mieszkalne i gospodarcze na terenie zachodniego podgrodzia oraz większość obiektów odkrytych w centralnej części grodziska.

Interesująca przy tym jest najmłodsza data dendro pozyskana z wewnętrznej ściany wału. Data „po 908 r.” wskazuje na to, że z aktywnością budowlaną na grodzisku mamy do czynienia jeszcze po tradycyjnie przyjmowanej przez historyków dacie upadku Wielkich Moraw około 906 r. (tzn. przed bitwą pod Bratysławą w 907 r.) ${ }^{30}$. Ta drobna informacja wpisuje się jednak w szerszy obraz wyłaniający się z badań

\footnotetext{
29 Z. Robak, Kotázke počiatkov, s. 56, 62-63; K. Pieta, Z. Robak, The Early Medieval, s. 343.

30 Por. Bitka pri Bratislave v roku 907 a jej význam pre vývoj stredného Podunajska, red. T. Štefanovičová, D. Hulinek, Bratislava 2008, gdzie zebrano różne hipotezy dotyczące znaczenia bitwy dla upadku Wielkich Moraw.
} 
archeologicznych ostatniego dziesięciolecia, który stoi w sprzeczności z dość kategorycznymi hipotezami historyków, opartymi na analizach źródeł pisanych i całkiem swobodnej interpretacji źródeł archeologicznych. Wyniki badań archeologicznych, zwłaszcza datowania dendrochronologicznego oraz analizy dużych serii dat radiowęglowych, dość wyraźnie wskazują na przetrwanie lokalnych struktur osadniczych, grodzisk i zasadniczą kontynuację dotychczasowego modelu kulturowego przynajmniej do połowy X w. ${ }^{31}$ Dotyczy to szczególnie obszarów dzisiejszej Słowacji, ale widoczne jest także i na Morawach ${ }^{32}$.

\section{Możliwa interpretacja}

Jaką właściwie funkcję pełniło grodzisko Bojná-Valy? Czy rzeczywiście stanowiło obiekt centralny i siedzibę elit, jak wydawało się to na początku badań archeologicznych? Czy możemy je uznać za typowe grodzisko, permanentnie zamieszkałe przez różne kategorie społeczne, czy też stanowiło tylko jakieś refugium? Jakie były przyczyny powstania takiego obiektu?

Przede wszystkim grodzisko Bojná-Valy nie wydaje się centrum polityczno-gospodarczym w takim znaczeniu, w jakim termin ten odnoszony jest np. do Mikulčic czy też aglomeracji Starégo Města. Już samo położenie w trudno dostępnym punkcie dyskwalifikuje je jako potencjalne centrum osadnicze. Wielkie aglomeracje wielkomorawskie są zlokalizowane w stosunkowo łatwo dostępnych dolinach rzecznych, gdzie ukształtowanie terenu nie ograniczało rozwoju osadnictwa otwartego, stanowiącego bezpośrednie zaplecze grodu. W przypadku Bojnej tego bezpośredniego zaplecza „obsługującego” gród na co dzień po prostu brak. Funkcje centrów aglomeracyjnych, a zatem i gospodarczych, już na pierwszy rzut oka mogły pełnić - i zapewne pełniły - pobliski Pobedim i całkiem nieodległa Nitra. W tym drugim wypadku centralne funkcje administracyjne grodu (od 880 r. stanowiącego też centrum diecezji) są bezspornie potwierdzone źródłami pisanymi. Istnienie drugiego takiego obiektu w odległości zaledwie $30 \mathrm{~km}$ byłoby dość nieracjonalne. Położenie Bojnej poza aglomeracjami, na skraju ekumeny, na granicy dwóch regionów osadniczych,

31 P. Bednár, M. Ruttkay, Nitra and the Principality, Brno 2018; B. Kovár, M. Ruttkay, Čo je kolaps?, [w: Kolaps očami archeológie, red. B. Kovár, M. Ruttkay, Nitra 2019, s. 13-29, tu s. $18-19$.

32 J. Macháček, P. Dresler, R. Přichystalová, Das Ende Großmährens - Überlegungen zur relativen und absoluten Chronologie des ostmitteleuropäischen Frühmittelalters, Prähistorische Zeitschrift 93 (2018), s. 307-348. 
w otoczeniu innych punktów obronnych (zob. ryc. 2) sugeruje raczej obiekt o charakterze refugialnym aniżeli nawet jakieś mniejsze, regionalne centrum politycznogospodarcze. Jednak ogromny zbiór militariów każe zastanowić się nad koncepcją, czy nie były to po prostu „koszary” - obiekt, w którym stałe przebywała określona liczba szeregowych wojowników i ewentualnie dowódców „średniego szczebla”, ich bezpośrednich zwierzchników.

Za powyższą hipotezą przemawiają następujące argumenty, stanowiące zresztą krótkie podsumowanie wyników badań:

1) gród powstał prawdopodobnie na „surowym korzeniu”, z dala od zasiedlonych obszarów. Grodzisko nie miało bezpośredniego zaplecza osadniczego, najbliższe zidentyfikowane osady oraz cmentarzyska (także z pochówkami wojowników) znajdują się w odległości kilku kilometrów, na skraju doliny rzeki Nitry, w pobliżu kordonu mniejszych punktów obronnych;

2) gród był ewidentnie chroniony przez kordon mniejszych obiektów. Znajdował się dokładnie na granicy dwóch wielkich skupisk osadniczych - poważskiego i nitrzańskiego. $\mathrm{Z}$ obu stron jest jednakowo dość trudno dostępny;

3) na grodzisku Bojná-Valy brak jest śladów budynków sakralnych, większych budynków o charakterze reprezentacyjnym oraz ewentualnego „dworu” jakiegoś wielmoży. Zabudowa mieszkalna wydaje się dość zunifikowana i ograniczona do jednego typu budynku - półziemianki z piecem;

4) na grodzisku ani w jego bezpośrednim pobliżu, pomimo ukierunkowanych i intensywnych poszukiwań, nie znaleziono do tej pory żadnego cmentarzyska. Stawia to pod znakiem zapytania trwałość osadnictwa w tym punkcie;

5) dostęp i bieżąca komunikacja z grodziskiem są utrudnione przez obiektu na wzgórzu o stromych zboczach. Ogromnie komplikowało to "codzienne” użytkowanie tego miejsca. Nie zidentyfikowano też źródła wody na samym grodzisku;

6) na grodzisku brak jest śladów produkcji ceramicznej. Naczynia znajdowane $\mathrm{w}$ warstwach i obiektach pochodzą z różnych warsztatów i zostały do grodu dostarczone z zewnątrz;

7) w próbkach gleby z wypełnisk obiektów nie stwierdzono obecności plew. Pozwala to przypuszczać, że zboże (którego obecność stwierdzono) było dostarczane do grodu już omłócone. Brak zatem śladów jednej z podstawowych czynności rolniczych. Należy przy tym zauważyć, że prowadzenie gospodarki rolnej na stromych zboczach okolicznych wzgórz (przy dostępności nieodległych żyznych dolin rzecznych Nitry i Wagu) nawet i dziś jest bezcelowe; 
8) w materiale zabytkowym wyraźnie przeważają militaria, zwłaszcza ostrogi i elementy ubioru oraz wyposażenia wojowników. Brak jednakże produktów naprawdę wysokiej klasy, porównywalnych z elitarnymi znaleziskami z Mikulčic, Starégo Města czy Břeclavia-Pohanska;

9) na grodzisku są wyraźnie zaznaczone ślady produkcji kowalskiej, zwłaszcza rzemiosła warsztatowego. Spora część militariów była zapewne produkowana na miejscu. Wydaje się, że były one tu powszechnie dostępne i tanie;

10) brak wyraźnej warstwy kulturowej świadczy o dość krótkim lub mało intensywnym użytkowaniu ostatniej fazy obiektu.

Stworzenie takiego obiektu jak Bojná-Valy znakomicie wpasowuje się w proces reorganizacji wielkomorawskich sił zbrojnych, rozpoczęty za czasów Świętopełka i zapewne kontynuowany po jego śmierci przez Mojmira II $^{33}$. Druga połowa IX i początek X w. upłynęły pod znakiem niemal ciągłych walk władców morawskich z sąsiadami, powodowanych bezustannym powstrzymywaniem prób uzależnienia od cesarstwa karolińskiego oraz agresywnym budowaniem własnej domeny. Czyniono to w sposób dość typowy dla wszystkich wczesnośredniowiecznych organizacji przedpaństwowych, tzn. przez bezustanny podbój sąsiadów, wymuszanie trybutów i zdobywanie łupów. Dochodziły do tego spory wewnętrzne oraz problemy z koczowniczymi Węgrami. Skutkowało to niemal ciągłymi konfliktami zbrojnymi, prowadzonymi ze zmiennym powodzeniem i przerywanymi tylko chwilowymi rozejmami. Tę nasiloną działalność militarną w drugiej połowie IX i na początku X w. odzwierciedlają źródła pisane ${ }^{34}$, przejawia się ona także w materiale archeologicznym i jest znakomicie czytelna we frekwencji zespołów grobowych wyposażonych w broń, datowanych na ten okres ${ }^{35}$.

Warunki polityczne, w jakich znalazło się „państwo” Mojmirowiców w drugiej połowie IX w. sprawiały, że stawało się nieodzowne niemal nieprzerwane utrzymywanie gotowości bojowej dość sporej grupy wojska. Podstawą sił zbrojnych, w miej-

\footnotetext{
33 A. Ruttkay, The Organization of Troops, Warfare and Arms in the Period of Great Moravian State, Slovenská archeológia 30 (1982), s. 165-198; tenże, O vel'komoravskom vojenstve s osobitným zretel'om na obdobie vlády Svätopluka, [w:] Svätopluk 894-1994, red. R. Marsina, A. Ruttkay, Nitra 1997, s. 175-189; tenże, Vojenstvo Vel'kej Moravy, [w: ] Vel'ká Morava a počátky křest'anství, red. P. Kouřil, Brno 2014, s. 70-78; L. Galuška, Slované - stopy předků. O Moravě v 6.-10. století, Brno 2017, s. 176-181.

34 A. Ruttkay, O vel'komoravskom vojenstve, s. 178.

35 Z. Robak, The Sword and Sword-belt, s. 170-171.
} 
sce arystokratycznej drużyny i pospolitego ruszenia, za czasów Świętopełka stali się więc wyspecjalizowani wojownicy, głównie jazda, wywodzący się z różnych warstw społecznych, nie tylko z arystokracji. Książę zapewniał im podstawowe uzbrojenie, wyżywienie lub utrzymanie i udział łupach w zamian za pozostawanie w gotowości bojowej. Można tu mówić o zapewne wymuszonej sytuacją pauperyzacji modelu wojownika, bowiem broń i oporządzenie musiały być produkowane masowo. Odpowiada to obserwowanemu w materiale zabytkowym wzrostowi znalezisk militariów $\mathrm{z}$ drugiej połowy IX w. przy jednoczesnym spadku jakości ich wykonania ${ }^{36}$.

W świetle tych argumentów nie wygląda nieracjonalnie hipoteza mówiąca o grodzisku Bojná-Valy jako o obiekcie typu koszarowego. Był znakomicie chroniony i trudno dostępny z zewnątrz. Mogłaby go zamieszkiwać stale określona liczba osób - głównie szeregowych żołnierzy i ich bezpośrednich dowódców, obsługiwana przez grupę rzemieślników, zwłaszcza metalurgów i kowali pracujących przede wszystkim $\mathrm{z}$ uzbrojeniem i elementami ubioru zwykłych wojowników. Przedmioty te były produkowane, naprawiane i składowane na miejscu do dyspozycji wojska, ale nie na własność indywidualnych żołnierzy. Żywność i przedmioty codziennej potrzeby były dostarczane z zewnątrz, z różnych miejsc. Brak śladów stałego pobytu elit tłumaczyłoby to, że po prostu na co dzień przebywały w nieodległej Nitrze. Także i część załogi „przypisanej” do grodziska nie musiałaby na nim stale przebywać, a mogła być rozlokowana w pobliskich wsiach, nawet na utrzymaniu miejscowej ludności i stawiać się tylko na wezwanie ${ }^{37}$. W czasach niebezpieczeństwa lub podejmowanej wyprawy takie „koszary” mogły z powodzeniem odgrywać rolę punktu mobilizacji i miejsca schronienia dla okolicznej ludności wraz z jej dobytkiem. W szerszej perspektywie obiekt ten mógł stanowić element tworzącej się sieci systemu grodowego umacniającego się organizmu politycznego i mieć na celu utrzymanie kontroli nad powierzonym mu obszarem ${ }^{38}$. Dlaczego nie był nim pobliski Pobedim? Być może

\footnotetext{
36 L. Galuška, Slované - stopy předků, Brno 2017, s. 180.

37 Z. Robak, The Sword and Sword-belt, s. 170.
}

38 Funkcję Bojnej jako elementu systemu grodowego księstwa nitrzańskiego może potwierdzać relacja anonimowego kronikarza króla Beli III (spisana około 1210 r.), odnosząca się do wydarzeń z początku X w. (Anonimowego notariusza króla Béli Gesta Hungarorum, tłum. A. Kulbicka, K. Pawłowski, G. Wodzinowska-Taklińska, Kraków 2006, rozdz. 35-37). Wspominany tam gród Bana, którego położenie w podanej konfiguracji geograficznej odpowiadałoby mniej więcej położeniu Bojnej, stanowi jeden z łańcucha wymienionych z nazwy pięciu grodów chroniących region Nitry od zachodu. Gród, podobnie jak i sąsiednie, nie został przez Węgrów zdobyty w wyniku oblężenia, ale poddał się po upadku Nitry. Relacja Nitra-Bojná byłaby więc typową relacją pomiędzy ośrodkiem decyzyjnym a strategicznie ulokowaną siedzibą „regionalną” 
położenie nie predysponowało go do funkcji twierdzy, a być może potężne w swej ostatniej fazie istnienia grodzisko Valy powstało na przykład już po zniszczeniu Pobedimia w czasie któregoś z konfliktów na przełomie IX i X w., niejako w reakcji na jego upadek? Wiemy, że zniszczenie grodu pod koniec IX w. nie oznaczało końca osadnictwa w jego okolicy ${ }^{39}$, być może jednak stanowiło początek Bojnej? A może oba obiekty przez jakiś czas wspólistniały? Kwestia ta jest przedmiotem trwających badań. Pozostaje tylko pytanie, czy - ze względu na swą nieporównywalną z niczym w pobliżu wielkość i rozmiary umocnień - grodzisko Valy nie pełniło przypadkiem funkcji głównego obiektu wojskowego dla całego regionu (księstwa) nitrzańskiego, a nie tylko środkowego Ponitrza?

Tabela 1. Wyniki datowań dendrochronologicznych próbek drewna elementów wałów

\begin{tabular}{|c|c|c|c|}
\hline Próbka/Sample & Obiekt/Feature & Słoje/Rings & $\begin{array}{c}\text { Prawdopodobna data ścięcia/ } \\
\text { Probable date of a cut }\end{array}$ \\
\hline C-51123 & $\begin{array}{l}\text { Wschodni wal } \\
\text { Eastern rampart }\end{array}$ & $798-846$ & $\begin{array}{l}\text { około/po } 866 \\
\text { about/after } 866\end{array}$ \\
\hline C-51125 & $\begin{array}{l}\text { Wschodni wal } \\
\text { Eastern rampart }\end{array}$ & $827-860$ & $\begin{array}{l}\text { około/po } 880 \\
\text { about/after } 880\end{array}$ \\
\hline $1 / 2007$ & $\begin{array}{l}\text { Wschodni wał } \\
\text { Eastern rampart }\end{array}$ & $\begin{array}{l}44 \text { słoje } \\
44 \text { rings }\end{array}$ & $\begin{array}{l}\text { około/po } 886 \\
\text { about } 886\end{array}$ \\
\hline C-51128 & $\begin{array}{l}\text { Wschodni wał } \\
\text { Eastern rampart }\end{array}$ & $788-869$ & $\begin{array}{l}\text { około/po } 889 \\
\text { about/after } 889\end{array}$ \\
\hline C-51129 & $\begin{array}{l}\text { Wschodni wal } \\
\text { Eastern rampart }\end{array}$ & $799-872$ & $\begin{array}{l}\text { około/po } 892 \\
\text { about/after } 892\end{array}$ \\
\hline C-51123 & $\begin{array}{l}\text { Wschodni wał } \\
\text { Eastern rampart }\end{array}$ & $808-876$ & $\begin{array}{l}\text { około/po } 896 \\
\text { about/after } 896\end{array}$ \\
\hline C-51121 & $\begin{array}{l}\text { Wał podgrodzia } \\
\text { Suburbium rampart }\end{array}$ & $754-879$ & $\begin{array}{l}\text { około/po } 899 \\
\text { about/after } 899\end{array}$ \\
\hline C-51127 & $\begin{array}{l}\text { Wschodni wal } \\
\text { Eastern rampart }\end{array}$ & $833-888$ & $\begin{array}{l}\text { około/po } 908 \\
\text { about/after } 908\end{array}$ \\
\hline
\end{tabular}

(por. P. Urbańczyk, Centralne funkcje grodów w społeczeństwach wczesnośredniowiecznych, Historia Slavorum Occidentis 2 (2019), s. 15).

39 J. Henning, M. Ruttkay, K. Daňová, Výskum včasnostredovekého hradiska v Pobedime, AVANS 2007 (2009), s. 75-77, 291-293; J. Henning, M. Ruttkay, Frühmittelalterliche Burgwälle an der mittleren Donau im ostmitteleuropäischen Kontext. Ein deutsch-slowakisches Forschungsprojekt, [w:] Frühgeschichtliche Zentralorte in Mitteleuropa, Internationale Konferenz und Kolleg der Alexander von Humboldt-Stiftung zum 50. Jahrestag des Beginns archäologischer Ausgrabungen in Pohansko bei Břeclav, 5.-9.10 2009, hrsg. v. J. Macháček, Š. Ungerman, Bonn 2011 , s. $259-288$, tu s. $268-270$. 
Nadesłany: 25 VII 2020

Nadesłany po poprawkach recenzyjnych: 25 I 2021

Zaakceptowany: 26 I 2021

Dr Zbigniew Robak

Archeologický ústav

Slovenská akadémia vied

ul. Akademická 2

94921 Nitra

Słowacja

zbigniew.robak@savba.sk

\section{Resume}

Following years of research, the Bojná-Valy hillfort in Slovakia no longer seems to have been a political and economic centre in the sense in which the term is used with reference to e.g. Mikulčice or the Staré Město agglomeration. The hillfort's very location, difficult to reach, disqualifies it as a potential settlement centre. The functions of agglomeration centres, and thus of economic centres, could have and probably were performed by the adjacent Pobedim and the even more proximate Nitra. A huge number of weaponry excavated at the hillfort, together with other facts indicating its use, lead to an assumption that the object served as a kind of barracks. The existence of this object, whose origin dates back to the late $9^{\text {th }}$ and the early $10^{\text {th }}$ centuries, connects perfectly with the reorganization of the Great Moravian forces during the reign of Svätopluk in the last quarter of the $9^{\text {th }}$ century.

Ttumaczenie: Ewa Dratwa 